This article was downloaded by: [Memorial University of Newfoundland] On: 21 January 2015, At: 17:24

Publisher: Routledge

Informa Ltd Registered in England and Wales Registered Number: 1072954

Registered office: Mortimer House, 37-41 Mortimer Street, London W1T 3J H, UK

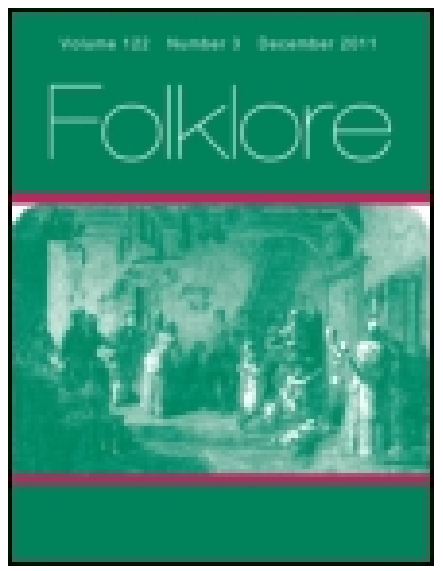

\title{
Folklore
}

Publication details, including instructions for authors and subscription information:

http:// www. tandfonline.com/loi/ rfol20

\section{Folklore from the Hebrides. IV.}

\author{
Malcolm Macphail ${ }^{a}$ \\ ${ }^{a}$ Free Church Manse, Kilmartin, Lochgilphead, N.B. \\ Published online: 06 Feb 2012.
}

To cite this article: Malcolm Macphail (1900) Folklore from the Hebrides. IV. , Folklore, 11:4, 439-450, DOI: 10.1080/ 0015587X. 1900.9719595

To link to this article: http:// dx.doi.org/ 10.1080/ 0015587X. 1900.9719595

\section{PLEASE SCROLL DOWN FOR ARTICLE}

Taylor \& Francis makes every effort to ensure the accuracy of all the information (the "Content") contained in the publications on our platform. However, Taylor \& Francis, our agents, and our licensors make no representations or warranties whatsoever as to the accuracy, completeness, or suitability for any purpose of the Content. Any opinions and views expressed in this publication are the opinions and views of the authors, and are not the views of or endorsed by Taylor \& Francis. The accuracy of the Content should not be relied upon and should be independently verified with primary sources of information. Taylor and Francis shall not be liable for any losses, actions, claims, proceedings, demands, costs, expenses, damages, and other liabilities whatsoever or howsoever caused arising directly or indirectly in connection with, in relation to or arising out of the use of the Content.

This article may be used for research, teaching, and private study purposes. Any substantial or systematic reproduction, redistribution, reselling, loan, sub-licensing, systematic supply, or distribution in any form to anyone is 
expressly forbidden. Terms $\&$ Conditions of access and use can be found at http://www.tandfonline.com/page/terms-and-conditions 


\section{MISCELLANEA.}

Fol ralore from the Hebrides. IV.

(With a few Notes from the Neighbouring Mainland.)

(Continued from Vol. ix., p. 93).

Agricultural Customs.-Ploughing.-Immediately. before beginning the spring labour, just when the horses were yoked to the plough and on the very spot of the farm where they were to begin the work of the season, the horses' harness and plough were three times carefully besprinkled with water in which some salt had been dissolved, and a little of the same solution was then poured into the horses' ears. After this last part of the ceremony had been gone through, the spring labour was considered to have been duly inaugurated. This ceremony was performed in the island of Arran within the last ninety years. ${ }^{1}$

In South Uist (a Roman Catholic district), when the ploughing season is being begun, the owner, just when ready to put the ploughshare into the soil, besprinkles the horses and all the ploughing implements with "holy water." This is regarded much more than an ordinary ceremony, as it is a matter of great interest to the whole family.

The ploughing season never begins on a Monday, according to the old adage, in which they firmly believe: "An rud a thoisecheas air Di-luain, bithidh e luath na mall," (What is begun on Monday will either be premature or late).

Plough-horses.-When horses in South Uist are let loose on the hill-pasture, after the spring work is over, a Snathainn (thread) is tied to the hair of the mane or tail as a charm against the "evileye" or any other mishap. The Snathainn is obtained from some charmer, either man or woman, who is believed to possess the

' It was an ancient custom to mix salt with the fodder of cattle. Isa. xxx. 24, "clean provender," or " salted food ; margin of R.V. "salted." 
power of imparting Seun (a charm for protection) to the Snathainn by repeating an incantation over it. For this Seun-Snathainn the geasadair (charmer) expects to receive a Sennseal (handsel). My informant saw these things done in South Uist a few years ago, and said they are still practised. 1

The First Day of Sowing.-I remember distinctly that in some of the districts of the island of Lewis the time of day selected for starting the sowing for the season was during the rising of the tide, and to avoid doing so during its fall, and, if at all convenient, to begin during spring-tide. It was considered more in harmony with the course of nature and more conducive to a rich harvest to begin the sowing during these seasons than at the falling of the tide or during neap-tide.?

A nail and an egg were placed in the Sgeap-a-chuire (sowingbasket) beneath the corn-seed. The bottom of the Sgeap was not to be seen till the sowing season was over. The nail was emblematical of long, strong, straight stalks of corn; the egg was symbolical of corn as full of substance as the egg is of meat; and the not seeing of the bottom of the sowing-Sgeap during the sowing season was an augury of abundance for the ensuing year.

Lite-ruire(Sowing-porridge), otherwise Lite-Mhanntan(Manntan's porridge), was porridge made of Ulag-meal, and made once a year only, of what remained over, after the sowing, of the grain that had been prepared and set apart for seed-corn. Thick porridge was made of this Ulag-meal. The thicker and richer the porridge the heavier and richer would be the crops in harvest.

This custom came down almost to our own times embodied in the following rhyme:-

\footnotetext{
" La lite Mhanntain,

Lá 'us fearr air bith;

An coire 'us an croucan,

'S a' maide crom air chrith."

"The day of Manntan's porridge,

The best day of all ;

Kettle-crook, and crooket-stick, Shaking like to fall."
}

'See Folk-Lore, vi., 154 , where a similar charm is figured, and the method of making and using it described.-E. S.' II.

In some parts of Argyllshire, if a house went on fire during the rising of the tide, it was considered a sure omen of future prosperity ; but if it happened during the fall of the tide it was taken as a sure sign of a future downcome in
life. 
Ulag was grain expeditiously dried for the quern, either in a pot over the fire or by a red-hot stone that was being kept perpetually rolling among the grain in a tub. The operator preserved his hands from being injured by the hot stone by keeping both his hands full of grain as he rapidly rolled the stone round. Ulag so made is the origin of the Gaelic proverb, which not many understand now : "Clach fo shiol" (stone under grain); or in full: "Tionndadh na claich fo'n t-siol" (turning the stone under the grain); in other words, "A rolling stone gathers no moss."

The Mhaighdean-Bhuana, or Reaping-Maiden, was the last sheaf of oats to be cut on a croft or farm. Before the reapingmachine and binder took the place of the sickle and the scythe, the young reapers of both sexes, when they neared the end of the last rig or field, used to manouvre to gain possession of the Mhaighdean-Bhuana. The individual who was fortunate enough to obtain it was ex officio entitled to be the King or the Queen of the Harvest-Home festival. The sheaf so designated was carefully preserved and kept intact until the day they began leading home the corn. A tuft of it was then given to each of the horses, as they started from the corn-field with their first load. The rest of it was neatly made up, and hung in some conspicuous corner of the farm-house, where it remained till it was replaced by a younger sister next season. On the first day of ploughing a tuft of it was given (as on the first day of leading home the corn) as a Sainnseal or handsel for luck to the horses. The Mhaighdean-Bhuana so preserved and used was a symbol that the harvest had been duly secured, and that the spring work had been properly inaugurated. It was also believed to be a protection against Fairies and Witcheraft.

I picked up the above note in the summer of 1897 from a farm manager in the neighbourhood of Kilmartin. A facsimile of the Mhaighdean-Bhuana, made by my informant, has been presented by me to the Society's Museum at Cambridge, November, 1900.1

FAIRY-LORE. - Na Sithichean a' ruamhar leis a' chois-chrium (The fairies delving with the crooked spade, lit. "crookedfoot"). - A certain poor man, who was at his wit's end with the spring labour, said one evening as the shades of night forced him to stop work: "B'aill leam gu'n robh m'aiteach criochnaichte"

' Cf. Folklore, vi., 149, 150.-E. S. II. 
(I wish my spring labour was finished). No sooner had he uttered this ordachadh-oidche (night-wishing) than a host of fairies appeared on the scene, and began delving his fields. In the morning he found that all his undelved land had been digged, and made ready for the seed. One of the fairies, however, had remained to bargain with him, for himself and his fellow habourers, as to hire. The wage the fairy asked was a sheal of corn in harvest for each labourer. To this the man willingly agteed.

He had a heavy crop in harvest-nine big stacks. The fairies did not forget to call for their Seannsal (handsel). Each of them came at the nick of time, and carried away a sheaf, as was agreed upon, till the field was cleared. The poor man sat dumbfoundered on a sheaf which he hoped to retain; but even this was to be taken away. One of the fairies who was minus his share gave unmistakable signs of fighting his way towards it. When the man observed how things were likely to end, he flung the sheaf at him, saying, as he did so: "Is miosa dh' fhidg na fhuar; oir tha sibh cho lionmhor ri muinntir Fhionlaidh" (You have left me in a worse plight than you found me in; for you are as numerous as the Finlay people).

-This is the supposed origin of the well-known Lewis adage, "As numerous as the Finlay people."

The name, Muinntir Fhionlaidh, "Finlay People," signifies the Clan Mackinlay. Why this name was given to the fairies I do not know, nor have I at present any means of ascertaining. It was, however, used as a euphemism for the fairies, to propitiate them when the party using it was anxious to obtain a favour at their hands, but under no other circumstances. As far 25 I know the name was confined to the island of Lewis. ${ }^{1}$

Dannsa-Sith (Fairy-dance). - A man who happened to be passing the Bruth Shith (Fairy Hill) with a 'buideal (cask) on his back, saw the door of the Bruth wide open, and the fairies as playful as kittens on the dancing floor. He went in and joined in the dance, with the buideal on his back. However, a year after, an acquaintance passed by the Bruth, and saw his missing neigh-

'According to Macbain's Gaelic Etymological Dictionary, the right spelling is Fionnlagh. The older genitive forms are Finlactic, fionniaoich, which seem to prove that the name means "Fair hero." It has been explained as "Fair calf," which would suit the phonetics also.-JOHN ABERCROMBY, Cf. a former communication frum Mr. MacPhail, $F . L$., vii., 402. 
bour "in high feather," on the fantastic toe. He ventured to go in, and to say: "Tha'n t-dm dhuit sguir a dhannsa. Cha'n eil cho fad sin on' thoisich mi ars' easan" (It is high time for you to stop dancing). He replied: "It is not so very long since I began." So pleased had he been with his employment that a whole year of it seemed to him, even with his burden on his back, less than no time.

Fairy Changelings. - When an infant did not happen to be thriving in the ordinary way, it was believed that the child was "in the knolls." (Theireadh iad gu'n robh e anns na cnuic.) That is to say, it was believed that the fairies had taken away the real child, and left one of their own in its place.

To get quit of the fairy-infant and to get their own restored, the parents or guardians placed the feeble, squealing child exactly in the march between two townships, uttering as they did so the euphemistical or magical formula, "Gu'n togadh Muinntir Fhionlaidh thu," (May the Finlay people take you away); and then went out of sight for a little. In a short time they returned, but in the interval they believed the fairies had returned the proper child, and had taken away their own. It is not more than a hundred years since such a ceremony was gone through in the island of Lewis. A very intelligent man of indisputable worth, then aged about seventy, who gave me this legend twenty-three years ago, told me that it had been performed in the days of his own father, in his immediate neighbourhood.

The following expressions are still in daily use among the Lewis people, though most of those who use them know nothing of their origin, viz.:- "Tha thu anns na cnuic" (Thou art in the knolls). "Is tu tha anns na cnuic" (lit. It is thou that art in the knolls), applied to a young person who is thin and stunted. The magic formula, slightly altered thus: "Togail Muinntir Fhionlaidh ort" (May you get the lifting or taking away of the Finlay people), is now used as a malediction. The common Lewis proverb, "Cho lionmhor ri Muinntir Fhionlaidh" (As numerous as the Finlay people), has already been referred to.

A certain mother, tradition says, was nursing a fairy instead of her own child: "Ach cha robh ire no piseach a' tighinn air, agus cha robh ràn a' dol as a' cheann" (But there was neither growth nor progress, and it never ceased crying). As it was ceaselessly crying one day, the supposed mother said to it : "Is mi tha seachd 
sgith dhiot" (I am seven times tired of you). To her amazement the supposed infant replied: "Ma ra, ars easan, na'n deanadh tu rin maith ormsa, bheirmise faochadh dhuit, agus dheanadh greis dannsa dhuit," (Well, said he, if you. would keep it a secret, I would give you some relief and would dance for you for a while.) She promised that she would. It set to it, in the likeness of a bodach beag sgiobalta (a little, smart old man). When it was tired with dancing, it returned to her lap, just in all respects as it was hefore. She told her friends what had happened. They advised her to put on a good fire, and to coax it to dance again, and when it was at it, to watch it, and to take the first opportunity that presented itself to throw it into the fire. She, as was directed, threw it into the fire, and it screaming ran out of the house. No sooner did it do so than her own child was at once imperceptibly restored.

In days long gone by, it was believed that the fairies could infect infants with various and strange diseases. The Hives, a malady incident to infants, is still called in some districts $A$ ' BhreacShlth, the Fairy-pox.?

Unbaptized Children.-In the Lewis, when the baptism of children was delayed, through parental neglect, beyond the ordinary period, the male child was called Maoldonuich (Ludovic), i.e., a devotee of St. Dominic; and the female, Creudach, i.e., a child of the Creed; originally to indicate that though unbaptized they were nevertheless under the protection of the Church. But when these names were sneeringly applied as nicknames by their neighbours, the careless parents were frequently compelled by the entreaties of their children to bring them to baptism that they might be freed from such taunts.

In some parts of the Southern Highlands (Argyllshire), almost within living memory, when a child died unbaptized, its funeral was delayed till after sunset. It was then brought to the churchyard and buried, as it was considered improper to bury it in full daylight. A young clerical friend, from Ross-shire, informed me quite lately, that he himself saw the above custom observed in his native district, about twelve years ago ; and said that, for anything he knows to the contrary, the same custom may still be in vogue.

LEecheraft (Baptismal Water used. in).-Baptismal water,

"Hives, Hyves, s. pl. Any eruption in the skin, proceeding from an internal cause. $S[$ cottish $]$. . . . . Hives is used to denote both the red and yellow gum. Loth[ian]" Jamieson's Scottish Dictionary, 1818.-ED. 
sipped immediately after the performance of the rite, was supposed to act as a charm to avert evil and insure good. A clergyman, from Sutherlandshire, told me quite recently that he himself had seen-within the last forty years-each of the members of a family, in which he had performed a baptismal service, take a sip from the baptismal font. He said he reproved them for their belief in such a silly superstition, and there and then put an end to the custom.

A cure for somnambulism was performed by pouring some of the baptismal water on the patient, while awake, but when occupied in conversation or otherwise, in so unexpected a manner as to cause a temporary shock. There are two females in my immediate neighbourhood who had been so treated within the last forty years.

If an infant was baptized with water in which a little wine had been mixed, instead of pure water, it was supposed to act as a protection against midge-bites ever after.

Birth Ceremony.-It was believed that if an infant's lips were made to lick the soil immediately after birth, this would confer the gift of speaking moderately, respectfully, and deferentially, as also to be both chaste and sparing of speech, during the whole course of one's after life. Though this custom long ago became a thing of the past, yet its echo is still heard in the adage scathingly applied by old people to over-talkative young ones: "Is e do chab nach do bhualadh anns an lar an latha rugadh tu" (It is your gab that was not made to lick the soil when you were born).

Remedies of various kinds.-A cure for flatulency in babies consisted in burning a small piece of the umbilical cord and grinding it into powder, then mixing it with water, and giving a little of this potion to the baby-patient to drink. This cure was performed to the certain knowledge of the writer about twenty years ago, by a native of Ross-shire, upon a native of Argyllshire.

At Duneistein, near the Butt of Lewis, there is a well at the base of a high rock quite close to the sea, which goes by the name of "Fuaran an déididh," Toothache Well, and which is supposed to cure the toothache. The cure consists in taking in succession three mouthfuls of the water of this well, which are to be kept in one's mouth as long as convenient. Then each mouthful is to be spurted out on a large stone in a cave close at hand; on which the sun never shines. People afflicted with toothache still resort to 
Fuaran an déididh for cure. The writer, in the sixties, was persuaded to do so. 1

A cure for epilepsy consisted in the patient taking a drink of water out of a newly dug-up human skull. The writer, as a boy, was well acquainted with a young man who was taken by his father to a burying-place at the time of a funeral, and made to take a drink from a skull that had then been dug up. It was said that he never after that had a fit.

A friend of mine told me quite recently, that when he was a boy in the Shawbost School, early in the sixties, one of his class-fellows, as he sat beside him at the writing-desk, took a fit of epilepsy. On the following day, his father and a man well known to the writer, of local fame for curing that dreadful malady, came to the schoolhouse. They opened the floor at the very spot at which the boy had the fit, and placed a living black cock, with clippings of the patient's hair and nails, in the opening made, covered it over, adjusted the floor to its usual level, and left the cock there. My friend said that be was in school with the boy for some time thereafter, and never saw or heard of his taking another fit. The unfortunate black cock has had a hard time of it, not only in the Highlands, but almost among all nations both barbarous and civilized."

To cure a swollen urula, the quack doctor took hold of a tuft of the patient's hair right above the uvula, and pulled it hard several times. The tuft of hair thus pulled was then tied round with a woollen thread, which is knotted several times. The

1 There were three other wells in Lewis noted for curious qualities : one at Loch Carloway that never whitens linen; St. Cowston's well at Garabost, which never boils any kind of meat, though it be kept on fire all day; and St. Andrew's well at Shiadair, which was made a test to know whether a sick person were to die or not. One was sent with a wooden dish to bring some of the water of this well to the patient. . If the dish, which was then laid softly upon the surface of the water, turned Deiseil (sun-ways), it was believed that the patient would recover, but if it turned Fuathal (way-of-North), that he would die. Vide MarTin, Western Isles, p. 7 .

" "Sacrifice of a Cock.-At Contin a boy took ill one day in school. Not long after the schoolmaster called at the boy's home to ask for the patient. . He entered quite unexpectedly.' He found him in bed, and on looking more narrowly he saw a hole below the bed with a cock lying dead in it." An old woman, a neighbour, was standing near the bed with her hands stained with blood. Rnss-shire." (MS. note of the late Rev. Dr. Gregor.) See also a previous communication by Mr. MacPhail, $F$. $L$, vi., 167. 
pulling, the tying and knotting were symbolical : the one, that it -the uvula-was to return to its normal condition; and the other, that it was to remain there. There is an old woman in my neighbourhood to whom old-fashioned patients still resort for a cure of the uvula. I have not yet learned whether or not she uses an incantation when performing the cure. After pulling and tying the hair, pepper is applied to the uvula.

Am Foomadh-iinn (the falling backwards), was a complaint incident to children when they began to walk. If a child fell backwards, and its head happened to strike violently against a hard substance, it was believed that such a fall displaced a bone in the roof of the mouth. The symptoms of the complaint were feverishness and looseness of the bowels. The quack-doctor performed his cure by placing his middle finger in the child's mouth, on the bone that was believed to be displaced, and placing his or her other hand against the back of the child's head and lifting it three times from the ground, its whole weight resting on the quack's finger in its mouth, and on his other hand against the back of its head. He then took the child in his arms, one arm below its neck and the other below its feet, the child lying on its back. With the child thus in his arms he went round the fireplace Deiseil (sunwise)-the fire had been previously removed from the hearth, and the hearth-stone swept-and touched the back of the child's head against the hearth-stone, and walked to the door. He repeated this performance also three times, and a cure was believed to be effected.

When a cow or sheep, or any other animal used as food, was found dead on the hill, its carcass must not be taken home, or utilised in any way, until one first went round it, Deiseil, sunways, with fire. The fire so used was called Teine-Naomh-Holy Fire. It is not more than ninety years since this custom was given up in some districts of the island of Lewis. My informant, a man about seventy years of age, told me-twenty-four years ago - that his own mother was among the first to discontinue this and similar customs. .

To cure the Aibigil, or colic in animals, the first person who observed the animal labouring under the painful convulsions of this disease was to make a left-handed rope-a rope made by his left hand- of grass or straw, whichever came most conveniently to hand; he was to put the rope round the animal's body, and 
then to burn it over its body. This was believed to be an effectual cure. I remember, as a dream, a friend of mine telling that he himself had observed a stirk of his own labouring under Aibigil pains as described above.

This cure has preserved a technical name for an animal disease, which is not to be found in any of our Gaelic dictionaries.

Healing Powers of Certain Persons.-A seventh son born in succession was believed to have the power of healing the scrofulous disease called the "King's Evil," by touching the affected parts with his hands. I knew two young men in the parish of Lochs, Lewis, to whom people resorted from all the surrounding districts to be cured of Tinneas an Righ-the king's evil. The so-called doctor was quite unconscious of possessing the virtue of healing which the popular mind ascribed to him.

A young man from the mainland of Ross-shire told me quite recently that on one occasion a woman who had travelled nine miles to a seventh-son-doctor in his native district, came to his parents' house and rested there, while he himself was sent to the doctor for water, in which the latter was to put his hands. She gave him a bottle for the water, and a silver coin, as a Seannsal (handsel) for the doctor. The doctor put his hands in water, and muttered something over it, which he could not catch. He then put the water into the bottle, and handed it to the youth, saying, "See to it, that you keep this bottle from touching the ground; if it once touches the ground its healing virtue is gone." : To wash the sores with water thus consecrated was considered equivalent to the doctor's touch.

. I remember, one day, when a little boy, being in the company of a reputed witch, who on seeing a $B$ ratag (the grass caterpillar), 1 said that one could heal scalds and burns with his tongue; if he would for that purpose consecrate it, by touching the Bratag with it.

There were some who professed to cure sprains by touching the sprained member by the tongue, and muttering an eora (incantation) over it. My young friend from Ross-shire saw an old woman of his acquaintance curing a sprain, as above described.

A living specimen kindly forwarded by Mr. MacPhail has been identified by Messrs. Watkins and Doncaster, naturalists. 36 , Strand, as the larva of the Fox-moth, Bombyx Rubi,-ED. 
She brought her mouth close to the sprained foot of his friend and muttered something over it, which he could not hear.

Verbal Charms. - I give the two following charms, the one for a sprain the other for a stye, on the authority of Mr. Archibald MacLeod, South Uist, Student in Divinity.

\section{Seun an t-Sniomha (Sprain Charm).}

A Phaidir an toiseach-Ürnuigh an Teagharna-Ägus aig a dhéireadh :-

"Chaidh Criosd a mach maduim mhoch.

Chunnaic e cnàmhan nan each air am bristeadh ma seach ;

Chuir e cneamh ri cneamh, chuir e smuais ri smuais ;

Chuir e féithe ri féithe, chuir e feòil ri feòil, chuir e fuil ri fuil:

Is mar a Chàraich e sin, gu'n càraich thu so."

First, the Lord's Prayer at the beginning and at the close of the charm :-..

"Christ went out at early mom.

He saw horses' bones broken and scattered;

He put bone to bone, and marrow to marrow ;

He put sinew to sinew, and flesh to flesh, and blood to blood

And as He repaired that, may you mend this."

Edra-Seun-air an Leamhragan (Charm for the Stye).

Bha'n eora so air agradh mar a leanas:-An toiseach.- " A Phaidir"-UUrninghan Tighearna, an deigh sin an edra mar so :-

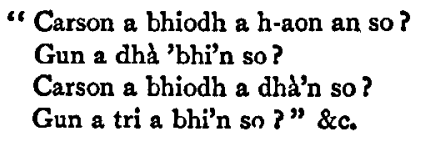

Agus mar sin gu ruige naoi, agus a phaidir aig a dheireadh. Agus dh'fheumadh an geasadair anail a chumail thad 'sa bhiodh $e$ ag radh na edra, air neo cha deanadh an edra leaghas, agus bha $i$ gu bhi air a radha air bucull a ghalais.

First the Lord's Prayer, then the charm :-

\footnotetext{
"Why there should be one here?

Without two being here?

Why there should be two here?

Without three being here?" \&c.

2 G
}

voL. XI. 
The numbers rise to nine, which is probably considered a mystic number. The other condition is that the charm is to be repeated at a breath and counted over a small buckle of the braces' belt.

Free Church Manse, Kilmartin, matcolm MacPhail. Lochgilphead, N.B.

\section{A FAIRY DOGS TOOTH.}

(Cf. Vol. viii., p. 382.)

Slightly abridged from a report in the Weekly Scotsman (Edinburgh), August 5, 1899, headed "Witchcraft in Lewis," and communicated by Mr. W. A. Craigie.

Kate MacCaskill or Campbell, a middle-aged woman, residing at Holm village, near Stornoway, was charged at Stornoway before Sheriff Campbell with committing a breach of the peace on $3^{\text {rst }}$ May last. Mrs. Mackay [the complainant], who gave her evidence in Gaelic, stated that on the occasion in question Mrs. MacCaskill had said to her that if she (Mrs. MacCaskill) had had the tooth she would use the peculiar properties possessed by said tooth to cause witness's immediate destruction. Mrs. MacCaskill had also remarked that had she the tooth she would have put it down witness's chimney, the result of which would be that witness's house would go on fire. The Sheriff asked witness various questions bearing on the subject. From her answers it appears that the tooth possessed certain curative properties, and that water in which it had been dipped could be used with most powerful healing effect on sick men or animals. Even the mere holding of the tooth produced this curing effect. His Lordship asked witness if the tooth was that of an animal. Witness replied that it was a fairy dog's tooth. At any rate that was the name it got.' She did not know where the tooth was now. It was considered a lucky possession. The Sheriff asked witness if the tooth was considered lucky how could it put her house on fire? Witness admitted she did not think it could do that. In further answer Mrs. Mackay. could not tell if the person who owned the tooth made money out of it or went about showing it to people. She (witness) had it in her hand ten years ago, and paid one shilling for this. The tooth was said to have come down from time immemorial. 